\title{
Political Branding, Public Sphere/Space and the Corruption of Communications
}

\author{
Bambang Sukma Wijaya \\ Universitas Bakrie \\ Jakarta, Indonesia \\ bswijaya98@yahoo.com
}

\author{
Andi Faisal \\ Univesitas Hasanuddin \\ Makassar, Indonesia \\ andifaisal.paskori@gmail.com
}

\begin{abstract}
In the 2014 Indonesia's presidential election,the frenetic of imaging communications and persuasion fulfilled the public space and sphere, involving not only the election campaign team of each candidates but also public participations at large. Using discursive approach with Habermasian's public sphere as an analytical tool, this paper examines how political branding, the corruption of communications and the discourse of public sphere/space intersect producing what we call the communication fog. We identified some forms of communication corruption in political branding in the public sphere/space during the 2014 presidential election, including the data manipulations, twistingand distortion of meaning, black campaign and media bias. We conclude that the higher the degree of corruption of communications in the public sphere/space, the lower the degree of democracy which marks the end of the political public sphere in a country.
\end{abstract}

Keywords—political branding; public sphere/space; the corruption of communications; communication fog;

\section{INTRODUCTION}

2014. The two stronghold candidates in Indonesia presidential election fought against each other. With every strategy used, each tried to strongly compete to gain as many votes as possible and make their supported candidate win. There has never been a battle as strong as this throughout the history of elections in Indonesia (suarasurabaya.net 3/6/2014).In contrast to the previous presidential elections sincethe post-new order era, the 2014 presidential elections indeed had only left the choices to only two sets of candidates that contested since the first round, namely Prabowo Subianto with Hatta Rajasa (Prabowo-Hatta) and Joko Widodo who is well-known as Jokowi with Jusuf Kalla (Jokowi-JK).Not surprisingly, the supports of the community were polarized into two campss facing each other with the full force, which can then be understood as a form of fanaticism and the death of logics spread even to the post-election (kompasiana.com/demosminimus 22/11/2014).

Even though the 2014 presidential election was notably known as a successful election which crowned Indonesia as one of the most successful populous democratic country, however 2014 presidential election also incised the dark history as a presidential election with an image that was full of political games that is less commendable both on the stage of pre-campaign, campaign, post-campaign, pre-election, election, and post-election. A lot forms of political branding and dirty communication strategies such as black campaign, slander, data manipulation, hoax, disinformation and over claim actions were done. For example: the data of violation claim in presidential election in form of 1 million documents that was intended to be brought in 15 armored cars and 2000 witnesses was never happened (merdeka.com 25/7/2014) or, the one-sided winning claim that was solely based on the result of self-count (kompas.com 9/7/2014).

There were at least 33 reports which were officially collected by Badan Pengawas Pemilu (election watchdog) related to alleged violations during the campaign from May 22 to June 27, 2014 (jpnn.com 28/6/2014).Meanwhile, the former leader of Muhammadiyah, a second largest Islamic organization, Ahmad Syafii Maarif noted four dark sides of 2014 presidential election that were mentioned as black campaign which resulted a lot of cruel slander, unhealthy competition among media tycoon, money politics, and meaningless tagline "ready to both win and lose" which came from both stronghold of the candidates and their supporters as the losing side were actually still failed to move on (BuletinBawaslu ed.12, 2014).Most of the violations and records were related to the events and communication actions that were blinding in public sphere, which taken away the public rights to receive the right message properly. This events and actions deserve to be called as the corruption of communications [1]. The corruption of communication can be happened in the various dimensions: message, media, context and behavioral dimensions [2].

This paper aims to discuss how the practice of political branding in the public sphere/space could potentially create a communication corruption. Smith and French [3] argued that the political brands must improve "meaningful connection, a sense of community and authenticity, while maintaining core brand values that are of relevance and use to voterconsumers". This is consistent with the definition of the brand itself as "a mark left on the minds and hearts of consumers, which creates a specific sense of meaning and feeling" [4] so that establishes a meaningful connection between brand and consumer (political brand and constituent or voter).

Political branding simply cannot be divorced from the communication strategy to enhance the image and reputation 
of the political brand, as well as supporting the goal of political marketing to persuade electorates to vote for a party or candidate [5]. Therefore, valuable political brand is very crucial for political parties and political leaders candidates to gain and sustain votes [6]. Needham and Smith [7] highlight the importance of political brand by quoting the statement of Scammell [8] that "the beauty of the brand as a concept is that it is broad and inclusive; it brings together the rational and apparently irrational, the hard and soft elements of voter choice".

However, the beauty of the brand could be a boomerang when ways are taken in political branding lead to actions that are less commendable, such as the spread of negative information in order to influence public perception [9]. The phrase 'marketing' in political marketing has also been widely misinterpreted as something that just solely on image building and its paraphernalia-spin doctors, publicity and news management, or advertising, so the strategy of just focusing on the use of large-scale media [10]. Savigny and Temple [11] criticize this model of political marketing which just drives media power as "the dog that does not bark" in polishing the image of the party or candidate. Therefore, it is necessary to redefine the substantive concept of 'image' in political branding, where reputation should be built based on the track record and credibility, not on the frippery of surface appearances [12]. The surface appearances will only entrap political branding in the cosmetic imaging strategy through instant impression management, so susceptible to the corruption of communications.

\section{METHOD}

The study focuses on the analysis of the forms of communication corruptions in the public space/sphere in political branding along the Indonesian presidential election of 2014, as well as examines the consequences for the development of the public sphere and the health of democracy. The first step that we did is gathering news and discussion about issues related to political branding activities during the 2014 presidential election, both in the pre-campaign, campaign, post-campaign, pre-election, election and postelection. Most of the news documents lasted for 2014, which can be tracked easily through online.

The next step we categorized findings based on the concepts in the dimensions of communication corruption to find the particular forms of corruptive communication in the political branding during the 2014 presidential election. From this point, we then discussed it using the perspective of Habermas's public sphere: how Habermasian sees this cases, how the theoretical claims about the public sphere dissect political branding practice that delivers corruptive communications, and how this unhealthy communication phenomenon has implications and consequences for the development of democracy and the political public sphere.

\section{RESULTS AND DISCUSSION}

\section{A. Political Branding and the Corruptive Communications}

Political branding cannot be separated from the strategies related to the image management of political parties and candidates [13]. Political branding also cannot be dissociated from the intent to influence potential voters to vote for parties and candidates on the election day [14].Therefore, political branding becomes prone to the corruption of communications, as the corrupt communications occur on many events and actions for the purpose of imaging communication and persuasion through impression management and impression laundering [15].

After a close examination of the discourse of political branding through online texts of news and talksduring the 2014 Indonesia presidential election, we observed several forms and patterns in which the corruption of communications happened such as data manipulation, the twist of meanings, black campaign, and media bias.

\section{Data Manipulations}

One of the corruptive communications in the political branding strategy, which were mostly done in the 2014 Indonesia presidential election, was data manipulation of the election results. It was done to create a winning discourse of a candidate. This can be seen based on the exposed chart of the quick count results that was done by one of the survey organization namely SaifulMujani. The data manipulation has caused the percentage of voting graphic became anomaly without any significant explanation (baritopasisia.id-hsb.com 13/7/2014). Thus, it was potentially misleading the public.

The same case happened in news from an online media HarianTerbit. It was published that the result of Lembaga Survey Nasional(LSN) showed that the candidatePrabowoHatta won clearly over the candidateJokowi-JK. Within the news, HarianTerbit quoted the information of survey results only solely based on LSN's survey results on several regions in Indonesia (harianterbit.com 29/6/2014).

Meanwhile, Kompas online published the opinions of Indonesian Survey Association that questioned the results of quick counts, which were done by four survey organizations that positioned Prabowo-Hatta as a winning candidate (harianterbit.com 9/7/2014). The association assumed that there were a potential data and sample manipulation related to the results of quick count that differed from the majority of other survey organizations.

\section{Twisting and Distortion of Meaning}

JokoWidodo, as a president candidate, considers that a cooperative for the fisherman and farmers in Indonesia has no longer been effective. JokoWidodo articulated this on June 17, 2014 when he was doing the campaign in Indramayu, West Java (viva.co.id 18/6/2014). 
Thereby was the opening line of Viva News online about Jokowi's point of view over the ineffectiveness of a cooperative to the fishermen and farmers.Jokowi preferred to replace the cooperative with a direct subsidiary fund.Media, undoubtedly, had twisted this news, because in presidential candidate debate held by KPU or KomisiPemilihanUmum [The General Election Commission], Jokowi disproved the idea that "the cooperative is no longer needed" as what has been pointed by another candidate, Prabowo to him. An incomplete information or a twisted fact could be a form of corruptive communication, which sometimes "allowed" to deliver a set of wrong information and make an established perspective over something, become blurry.

In dealing with wrong information or a twisted fact, DewanPers [Press Council] warned and advised the journalists to act professional and be more conscientious in exposing information without a relevant source that is aligned with the real situation (batamtoday.com 7/9/2015). The twisted information could be considered as a corruptive communication, because it has turned the fact upside down and making it different if compared to the real situation. It has also been a disgrace to the ethics and professionalism of journalists, which were supposed to voice out the truth without adding any twists or disclosed information from the public.

\section{Black Campaign}

Aside from the data manipulations, slanders and hoax also created and spread by political opponents as a way to discredit a candidate. In Tabloid Obor Rakyat (dated May 5-11, 2014) for example, it was found several headlines that were clearly intended to attack Jokowi, such as "A Toyed Candidate Who Loves to Give Empty Promises", "Held Hostage by Cukong [Well-to-do Financier] and (Christian) Missionaries", "From Solo to Jakarta: De-Islamization A La Jokowi", "Jacob Soetojo's Maneuver", “Cukong-cukong [Capitalists] behind Jokowi", "Cross Parties that Support Jokowi", and "Jokowi is the Failed Savior" (republika.co.id 1/7/2014). In addition, Jokowiwas also maligned as the Chinese and Christians with the name of Wie Jo Koh and HeribertusJokoWidodo. His bogus marriage certificate was widely spread through social media, not clear who had spread it, but allegedly was his political opponent from the camp of Prabowo-Hatta, or groups of haters who disliked his development programs and not want he was elected to be the seventh president of Indonesia.

The race and religion-related issues as the form of black campaign had become a political branding tool to attack the rival in 2014 presidential election, and influence the public not to choose the exposed candidate in the particular news. This became a corruptive communication that was spread in the public sphere/space.

\section{Media Bias}

Media in reporting also tend to ally with one of the candidates. This is because the media owners are also party activists who support one of the candidates. Metro TV, for example, clearly in framing the news tended to side with the candidate Jokowi-JK, where the owner, Surya Paloh is chairman Nasdem party that officially supported Jokowi-JK. Similarly, TV One owned by Aburizal Bakrie, chairman of Golkar party, which was officially declared support to Prabowo-Hatta. Other media, such as Kompas, Tempo and Tribune are nationalists, although officially the owners are not affiliated with a political party, but the framing of news tended to support Jokowi-JK, while Republika which is Islamist tended to support Prabowo-Hatta who was supported by many Islamist parties [16].However, the alignments of mediawhose the owners are not affiliated to any political party tended to be subtler than Metro TV and TV One. Both been involved in the black campaign and negative campaign,which has aggressively attacked the stronghold of political opponents, so they were reprimanded by KPI (KomisiPenyiaran Indonesia Indonesian Broadcasting Commission)(kpi.go.id 10/6/2014).

Of course this is a form of communication corruption in the media dimension. Media, with the power of capital ownership and broadcast rights arbitrarily packed news to frame the political interests of media owners. Public interest that requires an objective frame was ignored. Communication was corrupted through the packaging of news and information that was not neutral. SyafiiMaarif, former Muhammadiyah leader also noted that media bias is one of the black sides of the presidential election in 2014 (BuletinBawaslu ed.12, 2014). In political branding, the media indeed has the power in shaping the image of the political brand widely [17]. Media can also influence the electorate to vote for candidates who reported positively [18]. Thus, communication corruption through media in political branding has implications for the formation of perceptions and voting decision in unhealthily ways.

\section{B. Communication Corruptions and the End of Public Sphere}

The corruptive communications such as black campaign, data manipulations, disinformation, media bias and so on that were exposed in the online public sphere during 2014 presidential election, had actually been hurting the authentic meaning of public sphere itself. The public sphere, sincerely, should be freed (autonomous) from any kinds of corruptive communication behavior. As mentioned by Habermas that the (authentic) rational public spheres is the autonomous sphere as a pre-condition to achieving the continuity of democracy that is freed from any dominations and pressures.

The public sphere, ideally, should consist of spaces (conditions) that enable citizens (private spheres) to gather and articulate the various interests, form public opinion and finally agree upon a common will discursively [19]. The conditions meant by Habermas are first, all citizens are able to communicate and own equal rights to participate in the public sphere. Second, all participants have the same chance to reach the fair consensus and treat the communicants as the autonomous individuals that could be responsible, not as a tool 
to be used for particular interest. Third, there should be rules to protect the communication process from many pressures and discriminations, in order for a better argumentation as the foundation of the discussion process. In other words, in public spheres, the conditions (values) should be created are inclusive, egalitarian and freed from pressures [20].

In a particular public sphere, the ongoing interactions and communication reflect the public authority. This would make an ideal situation where opinions and discourse built in public spheres are originally come from public, by the public, and to the public interests. This has become the characteristic of civil society in a democratic country whereas the practices of power are always criticized through the public opinions and discourses. Interactions and autonomy of the communication are practiced in the public sphere, slowly it would form the public discourse in interrogating and controlling the practice of powers, and in its turn would influence the public acceptance towards an opinion.

If the communication spheres in the 2014 presidential election was not corrupted, limited and misused (as the form of corruption of communication), instead, the information channel and communication networks are widened, the public would have been exposed to more chances to discursively, rationally and critically problematize the communication practices of 2014 presidential election. It is a necessity because it could have the major impact on public acceptance towards a discussed public opinion. If the public opinion and acceptance are truly examined through a discursive, rational and critical communication process, the results of the interaction would be a "check and balance" process as the public acceptance and opinion in public sphere during 2014 presidential election, and this could come to be a real work of the power rationalization in between society.

The power rationalization in the 2014 presidential election is not only a process of deciding the rational purposes based on the rational consideration, it also goes to the extent of demanding a huge public involvement in the decision-making process. This means, the formed opinion from a critically rational discussion in 2014 presidential election should really reflect the society aspiration, because only the power that is determined by a critical public discussion that could be entitled as the rationalized power. This rationalization of power would then empower the democratic issue in the general communication gestures, and involve public that is freed from sensor and dominations institutionally.

To manifest the rationality of communication, Habermas portrayed 3 conditions or communication claims that must be provided to make an effective communication behavior. Firstly is to reveal something, one must be really honest, to tell the truth. Secondly, to tell the truth, one has to strive for justice for others. Thirdly, one has to be sincere and serious to create a relation to one another [21].Therefore, it could be concluded that an effective communication has to consider the truth, justice, and sincere factor, in the context of a communal living. In other words, the communication practice that is not corruptive would be able to happen if the practices in the public spheres are based on the healthy communication conditions, such as a communication that are fair, honest, equal and freed from the pressures. Without the conditions of healthy communication, it is impossible for the public to discuss, debate and interact critically and rational in forming the public discourse.

The practices of corruptive communication that were allowed during the 2014 presidential election such as data manipulations, lies and hoax, slander, the non-cover-both-side news, disinformation and so on had discharged to the rationality and critics from public to argue because the data and information are "fake" and "lies", thus makes the built opinions do not reflect the reality. To avoid that, the usage of ratio critically in various communication practices should be freed from every form of dominations, pressures, manipulation, because only by the utilization of ratio, it could bring betterment. To conclude, the communication rationality that is going on the public spheres should be based on the ideal conditions of a communication that widen to all publics and be freed from domination. These conditions of ideal communication are normative and evaluative towards the reality.

The rationality of communication assumes that human could reach a proper, fair, and sincere understanding only if one is freed from every constraint that deters to achieve the end goals. The constraints are not only in the area of social and politics but also in form of rationality. A communicative rationality enables to fight any kinds of colonialization in public spheres as well as the private sphere. The corruptive practices of communication that happened during the 2014 presidential election indicated that the public has not yet matured to communicate in public sphere, because maturity in public sphere requires the presence and responsibility towards what is delivered to the public, which is solely based on freedom and autonomy.

The matured public is the responsible public and freed (autonomous) from every domination and pressure, be it material or non-material. The communication practices that were going on in a presidential election should be ideally freed from any dominations and pressures, be it money domination or power domination, so it could result in an honest opinion that is authentically come from, by and for the interests of public and not for the interests of only certain groups or powers.

Therefore, a rational communication in public sphere would only possible in free and equal relationships in between subjects. In other words, a human relation is always between subjects (dialogic). Habermas argued that the most basic acts of human are communication or interaction, which is purposely intended to create understanding. If in a free (autonomous) communication an understanding is reached, this means rationality in a communication is also reached.

There is also a public sphere defined politically or political public sphere. It stands for how a public discussion formed 
based on the interests of individual, which are connected with the state power. A political public discussion is the public spheres that facilitate public and country interests, in which the public organize itself as the owner of public opinion based on the principles of democracy [22].The political public sphere is, essentially, the space of democracy for public to voice out their aspiration to the government as a holding power in a country. This means a particular public sphere comes from public interest, by public interests and also for a public themselves, without an interfere from any parties, such as individual or a group or even from the government. Therefore, essentially the public sphere is democratic values that defend the public interests. The maximum values of democratic are what becomes the core of political public sphere.

\section{CONCLUSION}

Seeing and analyzing several acts and corruptive behavior that had happened in political branding during 2014 Indonesia presidential election, showed that communication acts that were built in a political public sphere were indeed out of the government control. In this case, the state reduced its own power to give as much freedom to public discourse. However, this power is not easily reduced. This power and 'control' were shifted to certain groups (i.e. supporting group of candidates as well as the hidden groups that have political interests related to the 2014 presidential election) with the power of economic capital, social and political. They ran a political branding strategy by the creation of public discourses with the corrupted communications. It has made the political public sphere in the 2014 presidential election became eroded, not only by the power of government but instead the irrational communication power from several groups of citizen. Reducing the political public sphere is also reducing and hurting the meaning as well as the degree of the democracy itself.

Therefore, it can be said that the degree of corrupted communication in public sphere could show the portrayal of degree of democracy in a country. The bigger the corruption of communications that is going on in the public sphere, the less the degree of democracy in the public sphere. It also applies the other way around, the lesser amount of the corrupted communications the degree of democracy in the public sphere is maximized.

\section{ACKNOWLEDGEMENT}

We are grateful to the Graduate School of Media and Cultural Studies, GadjahMada University, Yogyakarta, Department of Communication Science, Bakrie University, Jakarta and the Department of Cultural Science, Hasanuddin University, Makassar, Indonesia, which have supported the success of this research.

\section{REFERENCES}

[1] B.S. Wijaya, "The corruptive communications," Ind. Transl "Komunikasi yang koruptif," proceeding of the National Conference on Communication and Corruption in Jakarta, July 2011, pp. 81-100

[2] B.S. Wijaya, "The corruption of communications in the message, media context and behavioral dimensions," Ind. Transl. "Korupsi komunikas dalam dimensi pesan, media, konteks dan perilaku: sebuah proposisi teoretis untuk riset," Journal communication spectrum, vol. 3 no. 1 , 2013, pp. 1-13

[3] G. Smith and A. French, "The political brand: a consumer perspective," Marketing theory, vol. 9, no. 2, 2009, pp. 209-226.

[4] B.S. Wijaya, "Dimensions of brand image: a conceptual review from the perspective of brand communication," European journal of business and management, vol. 5, no. 31, 2013, pp. 55-65

[5] M. Scammell, "Politics and image: the conceptual value of branding," Journal of political marketing, vol. 14, no. 1-2, 2015, pp. 7-18, doi: 10.1080/15377857.2014.990829

[6] A. Lock and P. Harris, "Establishing the Charles Kennedy brand," Journal of marketing management, vol. 17, no. 9-10, 2001, pp. 943-956, and see also C. Needham, "Brand leaders: Clinton, Blair and the limitations of the permanent campaign," Political studies, vol. 53, no. 2, 2005, pp. 343-361.

[7] C. Needham and G. Smith, "Introduction: political branding," Journal of political marketing, vol. 14, no. 1-2, 2015, pp. 1-6, doi: $10.1080 / 15377857.2014 .990828$

[8] M. Scammell, 2015, Op.cit.

[9] R. Ahluwalia and B. Shiv, "The effects of negative information in the political and marketing arenas: exceptions to the negativity effect", in Advances in consumer re-search, vol. 24, 1997

[10] J. Lees-Marshment, Political marketing \& British political parties, Manchester: Manchester University Press, 2001.

[11] H. Savigny and M. Temple, "Political marketing models: the curious incident of the dog that doesn't bark," Political studies, vol. 58, no. 5, 2010, pp. 1049-1064

[12] M. Harrop, "Political marketing," Parliamentary affairs, vol. 43, 1990, pp. 277-291, and also see M. Scammell, "Political marketing: lessons for political science,” Political studies, vol. 47, no. 4, 1999, pp. 718-739.

[13] M. Scammell, 2015, Op.cit.

[14] M. A. Ahmed, S. A. Lodhi and Z. Ahmad, "Political brand equity model: the integration of political brands in voter choice," Journal of political marketing, 2015, doi: 10.1080/15377857.2015.1022629

[15] B.S. Wijaya, 2013, Op.cit.

[16] B.S. Wijaya, "The 'realness' discourse of a political leader: a komunikasi berasa perspective," Journal of government and politics, vol. 7, no. 2, 2016, pp. 310-340

[17] M. Scammell, Op.cit.

[18] D. Swanson and P. Mancini, Eds., Politics, media and modern democracy, London: Praeger, 1996, and see also R. Ahluwalia and B. Shiv, "The effects of negative information in the political and marketing arenas. exceptions to the negativity effect", in Advances in consumer research, Vol. 24, 1997

[19] J. Habermas, The structural transformation of the public sphere: an inquiry into a category of bourgeois society, Transl. T. Burger, Cambridge: The MITT Press, 1993, pp. 27 \& 176

[20] Ibid., pp. 36-37

[21] Ibid, and see also Sindhunata, "Doing philosophy in the age of rising terror," Ind. Transl. "Berfilsafat di tengah zaman merebak teror," in Basis, Vol.11-12, Yogyakarta: Yayasan BP Basis, 2004, pp. 51

[22] J. Habermas, "The Public Sphere: An Encyclopedia Article," in Media and cultural studies, M. Durham and D. Kellner, eds, Massachusetts: Blackwell, 2002, pp. 102-103 